\title{
Different Corm Sizes Affect Performance of Gladiolus grandiflorus cvs. Red Majesty and Early Yellow
}

\author{
Abdul Kareem ${ }^{1, *}$, Muhammad Aslam Khan ${ }^{2}$, Shoib-UR-Rehman ${ }^{2}$, Irfan Afzal $^{3}$ \\ ${ }^{1}$ College of Agriculture Bahadur Sub-Campus Layyah, Bahauddin Zakariya University, Multan, Pakistan \\ ${ }^{2}$ Institute of Horticultural Sciences, University of Agriculture, Faisalabad \\ ${ }^{3}$ Department of Crop physiologies, University of Agriculture, Faisalabad \\ *Correspondence Author: karimalayani@yahoo.com
}

Copyright $(\subseteq 2013$ Horizon Research Publishing All rights reserved.

\begin{abstract}
Vegetative reproductive and corm characteristics of Gladiolus grandiflorus as affected by different corm sizes, large sized corm ( 3 to $3.5 \mathrm{~cm})$, medium ( 2 to $2.5 \mathrm{~cm}$ ) and to small (1 to $1.5 \mathrm{~cm}$ ) were evaluated under natural agro-climatic conditions of Faisalabad. The experiment was laid out in accordance with Complete Block Design with two factorial arrangements. Regarding vegetative parameters it was observed that sprouting percentage, plant height, number of leaves per plant and days required for $25 \%$ flowers, large sized corm perfume the best as compared to medium and small sized corms with maximum values $(96.67 \%),(56.02 \mathrm{~cm})$ and $(7.720)$ in variety red majesty (150.0 days) in variety Early Yellow respectively. Similar results were observed with reproductive characters, similar number of spikes per plant in both varieties in all corm sizes maximum thickness (1.023 $\mathrm{cm}$ ) of spike was observed in cvs. Early Yellow when large sized corms, spikes of maximum length in both cultivars being $47.55 \mathrm{~cm}$ and $47.50 \mathrm{~cm}$ in cv. Red Majesty and 45.56 and $43.11 \mathrm{~cm}$ in cvs. Early Yellow respectively, a significant difference was also in observed in number of florets per spike and intact flower life. In case of corm characters more number of cormels per plant was produced by plants raised by corms of large sized and corms size was increased with increase corm size
\end{abstract}

Keywords Gladiolus Gradiflorus, Red Majesty, Early Yellow, Different Corm Sizes, Cormlets, Spike Length

\section{Introduction}

Gladiolus (Gladiolus grandiflorus) is among the leading cut flowers and occupies eighth position in international cut flower trade (Ahmad et al., 2008). It is frequently used as cut flower in different social and religious ceremonies (Mitra, 1992). Gladiolus is very much liked for its majestic spikes which contain attractive, elegant and delicate florets. These florets open in a sequence over long duration and hence have a good keeping quality of cut spikes. The spikes of gladiolus are popular in flower arrangement and for preparing high-class bouquets (Mukhopadhay and Yadav, 1995).
There is a wide range of colours; self or bicolour, with or without central mark, varying from white to darkest crimson. There are many varieties of gladiolus available like White Friendship, T-210, Pink Parade, Traelor, Red Majesty, Aarti, Poonam, Hunting Song, Oscare, Praha. Mukta, Appleuse and Blue Mist etc.

In European countries during winter season, snow and frost check the flower production and there is dearness of fresh flowers in the market. We are fortunate by having temperate, subtropical and tropical climatic conditions in our country and can produce the fresh flowers round the year with little efforts and can export the commodity to outside the country but export of fresh flowers including gladiolus is quite insignificant from Pakistan.

Different factors such as size of corms and cormels, planting time and fertilizer management influence the production and quality of gladiolus flower (Arora and Khanna, 1990). Gladiolus is a corm which has solid shortened stem with buds systematically arranged under a paper-thin protective layer or scale usually one bud sprouts near the top of the corm when planted. It also produces cormlets. The basal roots are emerged and flower spike is visible and basal portion of shoot that begins to swell and develops into daughter corm. The daughter corm continues to enlarge after flowering and then nutrition is directed downward for storage. The daughter corm does not flower in the same season (Hudson et al., 1981).

The corm has direct effect on plant growth and flower quality (Sharga et al., 1984). At present there is an urgent need to standardize agrotechniques most suitable for local climate and edaphic conditions. The objective of present study was to evaluate the effect of different corm sizes of gladiolus cultivars for commercial propagation so as to have the best quality flower to meet the market demand.

\section{Materials and Methods}

The experiment was conducted at Floriculture Research Area, Institute of Horticultural Sciences, University of Agriculture, Faisalabad during the year 2005-2006 to study the effect of corm sizes on performance of gladiolus cvs. Red Majesty and Early Yellow. Corm size was 1 to $1.5 \mathrm{~cm}, 2$ to 
$2.5 \mathrm{~cm}$ and 3 to $3.5 \mathrm{~cm}$ in diameter as treatments for each variety. There were 18 corms in each treatment planted 5 $\mathrm{cm}$ deep at a spacing of $30 \mathrm{~cm} \mathrm{x} 45 \mathrm{~cm}$. The size of main plot was 15 feet x 18 feet. There were six ridges in a sub plot and six corms were planted on each ridge. First irrigation was given just after sowing and then subsequent irrigation was applied as per crop requirement. All standard cultural practices required for raising crop were practiced. The experiment was laid out according to Completely Randomized Block Design with Factorial Design arrangement. Data were collected on various growth, flowering and corm characteristics like sprouting percentage. Plant height, number of leaves per plant, length of spike per plant, number of florets per spike, intact flower life, average number of corms and average size of corms. The data collected on various characters were statistically analyzed using the Fisher's analysis of variance technique. The treatments were compared by Least Significance Difference at 5 percent level of significance (Steel and Torrie, 1984).

\section{Results and Discussion}

\section{Sprouting percentage}

Corm size significantly affected sprouting percentage (Table 1). Sprouting percentage increased with increase in corm size being maximum $(96.67 \%)$ in the largest size (3 to $3.5 \mathrm{~cm})$ in cv. Red Majesty and lowest sprouting percentage $(71.56 \%)$ was found in smallest corm size (1 to $1.5 \mathrm{~cm})$ in cv. Early Yellow. In combine effect of treatments $(3-3.5 \mathrm{~cm})$ treatment performed the best while lowest results were found in in treatment $(1-1.5 \mathrm{~cm})$ in both varieties as indicated in figure 3. For combined effect of varieties the variety Red Majesty performed best Figure 4. Possible reason for this is that large sized corms have comparatively short dormancy period as compared to small sized ones which helped in quick emergence of gladiolus (Ogele et al., 1995).

Table 1. Main effect of corm size on different corm sizes and varieties on performance of gladiolus cv. Red Majesty and Early Yellow Red Majesty

\begin{tabular}{|c|c|c|c|c|c|c|c|c|c|c|c|}
\hline $\begin{array}{l}\text { Treatments } \\
\text { (Corm } \\
\text { Size) }(\mathrm{cm})\end{array}$ & $\begin{array}{l}\text { Sprouting } \\
\text { Percentage }\end{array}$ & $\begin{array}{l}\text { Plant } \\
\text { Height } \\
\text { (cm) }\end{array}$ & $\begin{array}{c}\text { Number } \\
\text { of } \\
\text { leaves } \\
\text { plant }^{-1}\end{array}$ & $\begin{array}{l}\text { Days for } \\
\text { flowering } \\
\text { in } 25 \% \\
\text { flowers }\end{array}$ & $\begin{array}{l}\text { Number } \\
\text { of Spike } \\
\text { plant }^{-1}\end{array}$ & $\begin{array}{l}\text { Thickness } \\
\text { of Spike } \\
\text { plant }^{-1}\end{array}$ & $\begin{array}{c}\text { Length } \\
\text { of } \\
\text { Spike } \\
\text { plant }^{-1}\end{array}$ & $\begin{array}{l}\text { Number } \\
\text { of } \\
\text { florets } \\
\text { Spike }^{-1}\end{array}$ & $\begin{array}{l}\text { Intact } \\
\text { flower } \\
\text { life }\end{array}$ & $\begin{array}{c}\text { Number } \\
\text { of } \\
\text { Cormels } \\
\text { plant }^{-1}\end{array}$ & $\begin{array}{c}\text { Average } \\
\text { size of } \\
\text { Corms }\end{array}$ \\
\hline $1-1.5$ & $73.35 \mathrm{~b}$ & $35.74 b$ & $6.127 \mathrm{a}$ & $149.4 \mathrm{a}$ & $1.00 \mathrm{a}$ & $0.640 \mathrm{~b}$ & $31.29 \mathrm{~b}$ & $5.853 \mathrm{~b}$ & $16.64 b$ & $4.487 \mathrm{~b}$ & $3.067 \mathrm{~cd}$ \\
\hline $2-2.5$ & $86.67 \mathrm{a}$ & $54.12 \mathrm{a}$ & $7.693 \mathrm{a}$ & $109.9 \mathrm{~b}$ & $1.00 \mathrm{a}$ & $0.940 \mathrm{a}$ & $47.55 \mathrm{a}$ & $7.827 \mathrm{a}$ & $22.12 \mathrm{a}$ & $8.507 \mathrm{ab}$ & $4.667 \mathrm{ab}$ \\
\hline $3-3.5$ & $96.67 \mathrm{a}$ & $56.02 \mathrm{a}$ & $7.720 \mathrm{a}$ & $109.9 \mathrm{~b}$ & $1.00 \mathrm{a}$ & $0.986 \mathrm{a}$ & $47.50 \mathrm{a}$ & $8.317 \mathrm{a}$ & $21.78 \mathrm{a}$ & $8.767 \mathrm{a}$ & $5.900 \mathrm{a}$ \\
\hline
\end{tabular}

Early Yellow

\begin{tabular}{|c|c|c|c|c|c|c|c|c|c|c|c|}
\hline $\begin{array}{l}\text { Treatments } \\
\quad(\text { Corm } \\
\text { Size })(\mathrm{cm})\end{array}$ & $\begin{array}{c}\text { Sprouting } \\
\text { Percentage }\end{array}$ & $\begin{array}{l}\text { Plant } \\
\text { Height } \\
(\mathrm{cm})\end{array}$ & $\begin{array}{c}\text { Number } \\
\text { of } \\
\text { leaves } \\
\text { plant }^{-1}\end{array}$ & $\begin{array}{l}\text { Days for } \\
\text { flowering } \\
\text { in } 25 \% \\
\text { flowers }\end{array}$ & $\begin{array}{l}\text { Number } \\
\text { of Spike } \\
\text { plant }^{-1}\end{array}$ & $\begin{array}{c}\text { Thickness } \\
\text { of Spike } \\
\text { plant }^{-1}\end{array}$ & $\begin{array}{c}\text { Length } \\
\text { of } \\
\text { Spike } \\
\text { plant }^{-1}\end{array}$ & $\begin{array}{c}\text { Number } \\
\text { of } \\
\text { florets } \\
\text { Spike }^{-1}\end{array}$ & $\begin{array}{l}\text { Intact } \\
\text { flower } \\
\text { life }\end{array}$ & $\begin{array}{l}\text { Number } \\
\text { of } \\
\text { Cormels } \\
\text { plant }^{-1}\end{array}$ & $\begin{array}{c}\text { Average } \\
\text { size of } \\
\text { Corms }\end{array}$ \\
\hline $1-1.5$ & $71.56 \mathrm{~b}$ & $15.11 \mathrm{c}$ & $2.033 \mathrm{~b}$ & $150.00 \mathrm{c}$ & $0.33 \mathrm{~b}$ & $0.586 \mathrm{~b}$ & $10.89 \mathrm{c}$ & $3.627 \mathrm{c}$ & $8.563 b$ & $4.333 b$ & $1.833 \mathrm{~d}$ \\
\hline $2-2.5$ & $82.33 \mathrm{a}$ & $55.17 \mathrm{a}$ & $6.960 \mathrm{a}$ & $110.2 \mathrm{a}$ & $1.00 \mathrm{a}$ & $0.980 \mathrm{a}$ & $45.56 \mathrm{a}$ & $7.303 \mathrm{ab}$ & $21.35 \mathrm{a}$ & $8.333 \mathrm{ab}$ & $4.400 \mathrm{ac}$ \\
\hline $3-3.5$ & $93.52 \mathrm{a}$ & $52.46 \mathrm{a}$ & $6.267 \mathrm{a}$ & $113.2 \mathrm{ab}$ & $1.00 \mathrm{a}$ & $1.023 \mathrm{a}$ & $43.11 \mathrm{a}$ & $6.773 \mathrm{ab}$ & $21.69 \mathrm{a}$ & $8.333 \mathrm{ab}$ & $5.400 \mathrm{ab}$ \\
\hline
\end{tabular}

Table 2. Combined effect of corm size on different corm sizes and varieties on performance of gladiolus cv. Red Majesty and Early Yellow

Combined effect of Treatments

\begin{tabular}{|c|c|c|c|c|c|c|c|c|c|c|c|}
\hline $\begin{array}{l}\text { Treatments } \\
\text { (Corm } \\
\text { Size) }(\mathrm{cm})\end{array}$ & $\begin{array}{c}\text { Sprouting } \\
\text { Percentage }\end{array}$ & $\begin{array}{l}\text { Plant } \\
\text { Height } \\
(\mathrm{cm})\end{array}$ & $\begin{array}{c}\text { Number } \\
\text { of } \\
\text { leaves } \\
\text { plant }^{-1}\end{array}$ & $\begin{array}{l}\text { Days for } \\
\text { flowering } \\
\text { in } 25 \% \\
\text { flowers }\end{array}$ & $\begin{array}{l}\text { Number } \\
\text { of Spike } \\
\text { plant }^{-1}\end{array}$ & $\begin{array}{c}\text { Thickness } \\
\text { of Spike } \\
\text { plant }^{-1}\end{array}$ & $\begin{array}{c}\text { Length } \\
\text { of } \\
\text { Spike } \\
\text { plant }^{-1}\end{array}$ & $\begin{array}{l}\text { Number } \\
\text { of } \\
\text { florets } \\
\text { Spike }^{-1}\end{array}$ & $\begin{array}{l}\text { Intact } \\
\text { flower } \\
\text { life }\end{array}$ & $\begin{array}{c}\text { Number } \\
\text { of } \\
\text { Cormels } \\
\text { plant }^{-1}\end{array}$ & $\begin{array}{c}\text { Average } \\
\text { size of } \\
\text { Corms }\end{array}$ \\
\hline $1-1.5$ & 2.220 & 25.425 & 4.08 & 99.713 & 0.665 & 0.77 & 16.59 & 3.74 & 12.603 & 4.410 & 2.450 \\
\hline $2-2.5$ & 5.832 & 54.515 & 7.32 & 110.055 & 1.000 & 0.96 & 46.55 & 7.565 & 21.735 & 8.420 & 4.533 \\
\hline $3-3.5$ & 5.718 & 54.241 & 6.99 & 111.553 & 1.000 & 1.005 & 45.06 & 7.545 & 21.738 & 8.550 & 5.650 \\
\hline
\end{tabular}

Combined effect of varieties

\begin{tabular}{|c|c|c|c|c|c|c|c|c|c|c|c|}
\hline $\begin{array}{c}\text { Varieties } \\
\text { (Early } \\
\text { Yellow and } \\
\text { Red } \\
\text { Majesty) } \\
\end{array}$ & $\begin{array}{l}\text { Sprouting } \\
\text { Percentage }\end{array}$ & $\begin{array}{l}\text { Plant } \\
\text { Height } \\
\text { (cm) }\end{array}$ & $\begin{array}{c}\text { Number } \\
\text { of } \\
\text { leaves } \\
\text { plant }^{-1}\end{array}$ & $\begin{array}{l}\text { Days for } \\
\text { flowering } \\
\text { in } 25 \% \\
\text { flowers }\end{array}$ & $\begin{array}{l}\text { Number } \\
\text { of Spike } \\
\text { plant }^{-1}\end{array}$ & $\begin{array}{c}\text { Thickness } \\
\text { of Spike } \\
\text { plant }^{-1}\end{array}$ & $\begin{array}{c}\text { Length } \\
\text { of } \\
\text { Spike } \\
\text { plant }^{-1}\end{array}$ & $\begin{array}{l}\text { Number } \\
\text { of } \\
\text { florets } \\
\text { Spike }^{-1}\end{array}$ & $\begin{array}{c}\text { Intact } \\
\text { flower } \\
\text { life }\end{array}$ & $\begin{array}{l}\text { Number } \\
\text { of } \\
\text { Cormels } \\
\text { plant }^{-1}\end{array}$ & $\begin{array}{c}\text { Average } \\
\text { size of } \\
\text { Corms }\end{array}$ \\
\hline $\mathrm{V}_{1}$ & 5.071 & 48.63 & 7.18 & 123.069 & 1.000 & 0.96 & 43.945 & 7.332 & 20.182 & 7.253 & 4.544 \\
\hline $\mathrm{V}_{2}$ & 4.109 & 40.915 & 5.09 & 91.144 & 0.077 & 0.864 & 33.189 & 5.234 & 17.202 & 7.000 & 3.878 \\
\hline
\end{tabular}




\section{Plant Height (cm)}

There was a significant difference among different corm sizes for plant height. Plant height $(56.02 \mathrm{~cm})$ in large corm sized ( 3 to $3.5 \mathrm{~cm}$ ) in $\mathrm{cv}$. Red Majesty and the minimum height $(15.11 \mathrm{~cm})$ were found in cv. Early Yellow in corm size $(1$ to $1.5 \mathrm{~cm})$. The combined effects for plant height indicated highest results for treatment $(3-3.5 \mathrm{~cm})$ as intratment $(2-2.5 \mathrm{~cm})$ and lwest results were found in treatment $(1-1.5 \mathrm{~cm})$ as shown in Figure 3. Figure 4 indicates the results for combine effects of varieties, the variety Red Majesty perform the best. This may be due to more storage reserves in large sized corms $(3$ to $3.5 \mathrm{~cm}$ ) which helped in early and rapid vegetative growth of the plant. Plant height in small sized corms of the two varieties was significantly different more in cv. Red Majesty than in cv. Early Yellow indicating superiority of small sized corms of former cv. over the later one. These results were supported by the Mahanta et al. (1998) who found that height of plant was enhanced with increasing corm sizes in tuberose due to reserved food.

Number of Leaves Plant ${ }^{-1}$

Number of leaves plant ${ }^{-1}$ was significantly influenced by corm size (Table 1). Large sized corms $(3 \mathrm{~cm}$ to $3.5 \mathrm{~cm})$ produced maximum number of leaves (7.720) and (Table 2) in cv. Red Majesty while minimum number of leaves (16.96) was found in small sized corms $(1 \mathrm{~cm}$ to $1.5 \mathrm{~cm})$ in Early Yellow. Number of leaves per plant was statistically at par for all corm sizes in cv. Red Majesty and also at par with number of leaves for medium and large sized corms. Figure 3 indicates the combined effects of treatments; the treatment $(3-3.5 \mathrm{~cm})$ performed the best for number of leaves with more number of leaves as compared to treatment $(1-1.5 \mathrm{~cm})$ with lowest number of leaves. It is clear from Figure 4 that the variety Red Majesty was found with more number of leaves. These results are in alliance with the results of Farid Uddin et al. (2002) who reported that corm size has significant effect on number of leaves plant ${ }^{-1}$. Results depicted that for cv. Red Majesty corms of small, medium and large size perform equally well while for cultivating cv. Early Yellow only medium and large sized corms should be used.

\section{Days Required for $\mathbf{2 5 \%}$ Flowers}

Time taken to complete $25 \%$ visible first inflorescence of the crop was significantly influenced by corm size (Table 1) and (Figure 1). Small sized corm (1 to $1.5 \mathrm{~cm})$ required maximum time to $25 \%$ flowering in both cvs. i.e. 149.4 and 150.0 days in cv. Red Majesty and Early Yellow respectively.
The time taken to complete $25 \%$ visible first inflorescence initiation of gladiolus crop was found to be delayed gradually with the decrease in corm size. However, it was noticed that flowering started comparatively earlier in cvs. Red Majesty as compared to Early Yellow when the performance of large sized corms was observed. The combined effects of treatments indicate les number of days were required in treatment $(3-3.5 \mathrm{~cm})$ than other treatments as clear from Figure 3. The variety Red Majesty take less number of days for $25 \%$ flower completions described in Figure 4. These results were supported by Kalasareddi et al. (1997) who found that large corms flowered earlier in gladiolus. Earlier flowering may be due to more food reserves present in large and medium sized corms as compared to small ones which produced more number of leaves. These corms with more leaves were able to produce bloom earlier than small sized ones.

\section{Number of Spikes Plant ${ }^{-1}$}

Corm size had no effect on number of spikes per plant in both varieties as in Table 1.Equal number of spikes was noted in all corm sizes while large and medium sized corms produced significantly more spikes plant- 1 than small ones in cv. Early Yellow.The combined effects of treatment indicated same results for both varieties as indicated in Figure 3 and 4. Spike production is a genetic factor for survival of the individual corm.

\section{Spike Thickness}

Results showed significant effect of corm size on spike thickness. Spike of maximum thickness $(1.023 \mathrm{~cm})$ was observed in cv. Early Yellow when large sized corms were planted. Results were statistically at par with corms of medium size, which produced spikes of $0.980 \mathrm{~cm}$ thickness (Figure 2). Large and medium sized corms in cv. Red Majesty produced spikes which statistically had same thickness. Figure 3 indicate combined effects for thickness of spike per plant, the thicker spike were found in treatment $(3-3.5 \mathrm{~cm})$ and thin spikes were found in treatment $(1-1.5 \mathrm{~cm})$ as indicated in Figure 3. Thicker spikes were found in found in variety Red Majesty, that performed the best as declared by figure 4 . Results indicate that spike thickness is affected by corm thickness. Corms of size less that $2 \mathrm{~cm}$ gave rise to thin spikes which are more prone to lodging. So corms for commercial propagation should be of 2 or more than $2 \mathrm{~cm}$. 


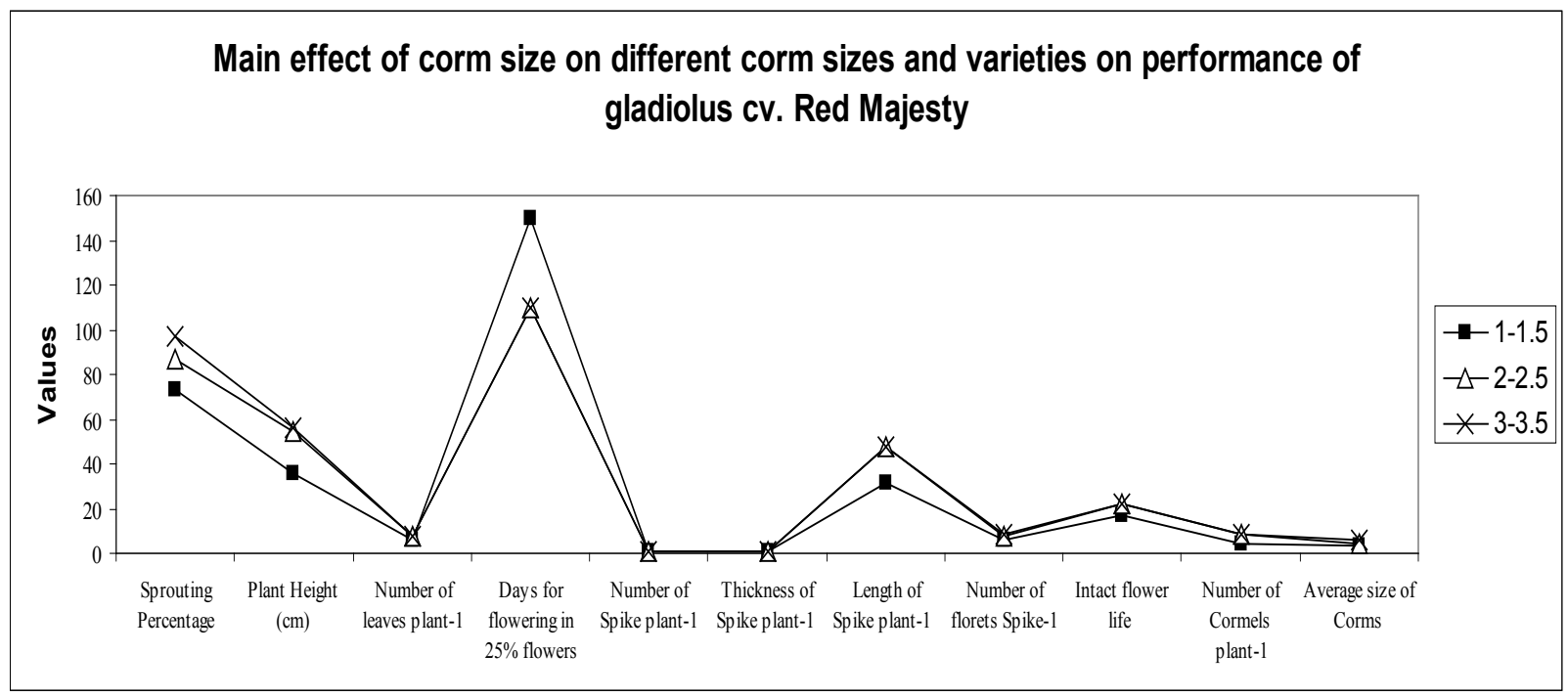

Figure 1. Main effect of corm size on different corm sizes and varieties on performance of gladiolus cv. Red Majesty

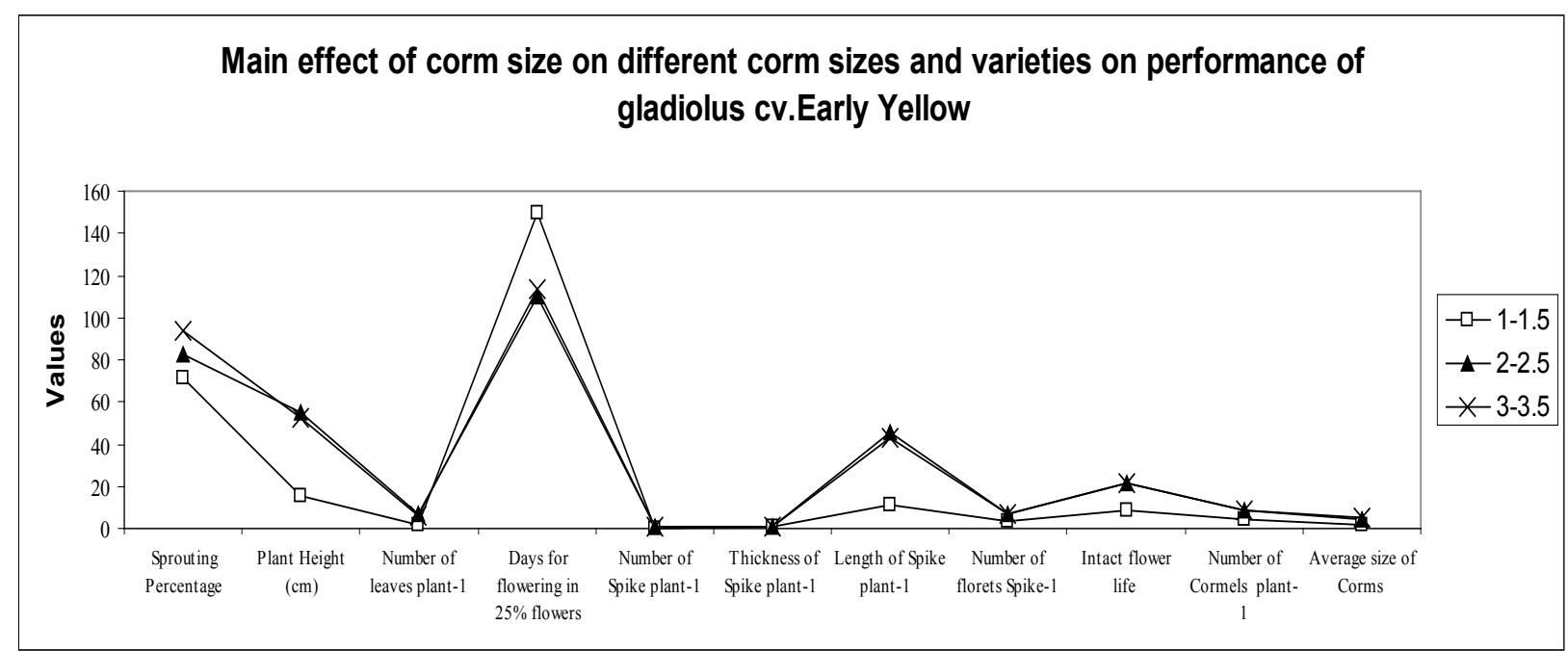

Figure 2. Main effect of corm size on different corm sizes and varieties on performance of gladiolus cv. Early Yellow

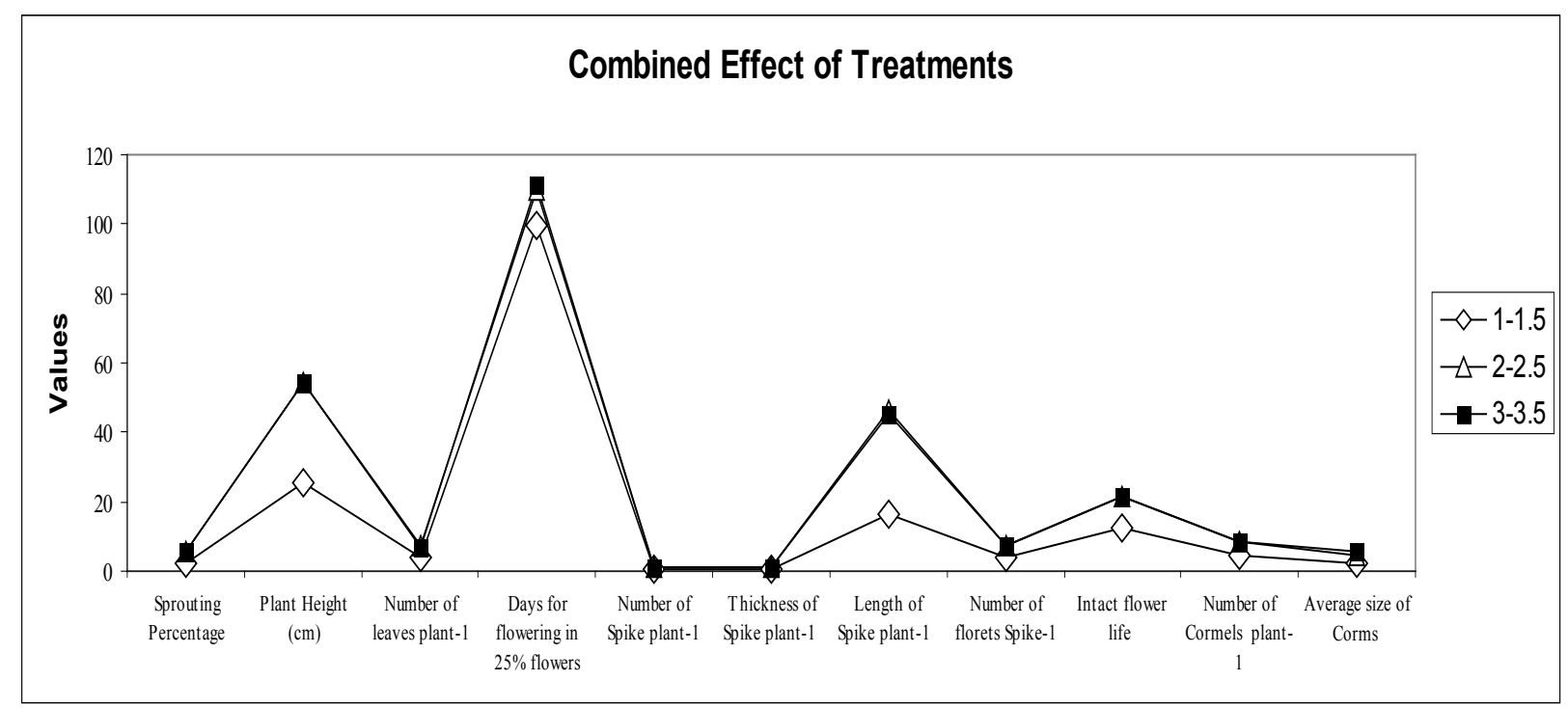

Figure 3. Combined effect of treatment 


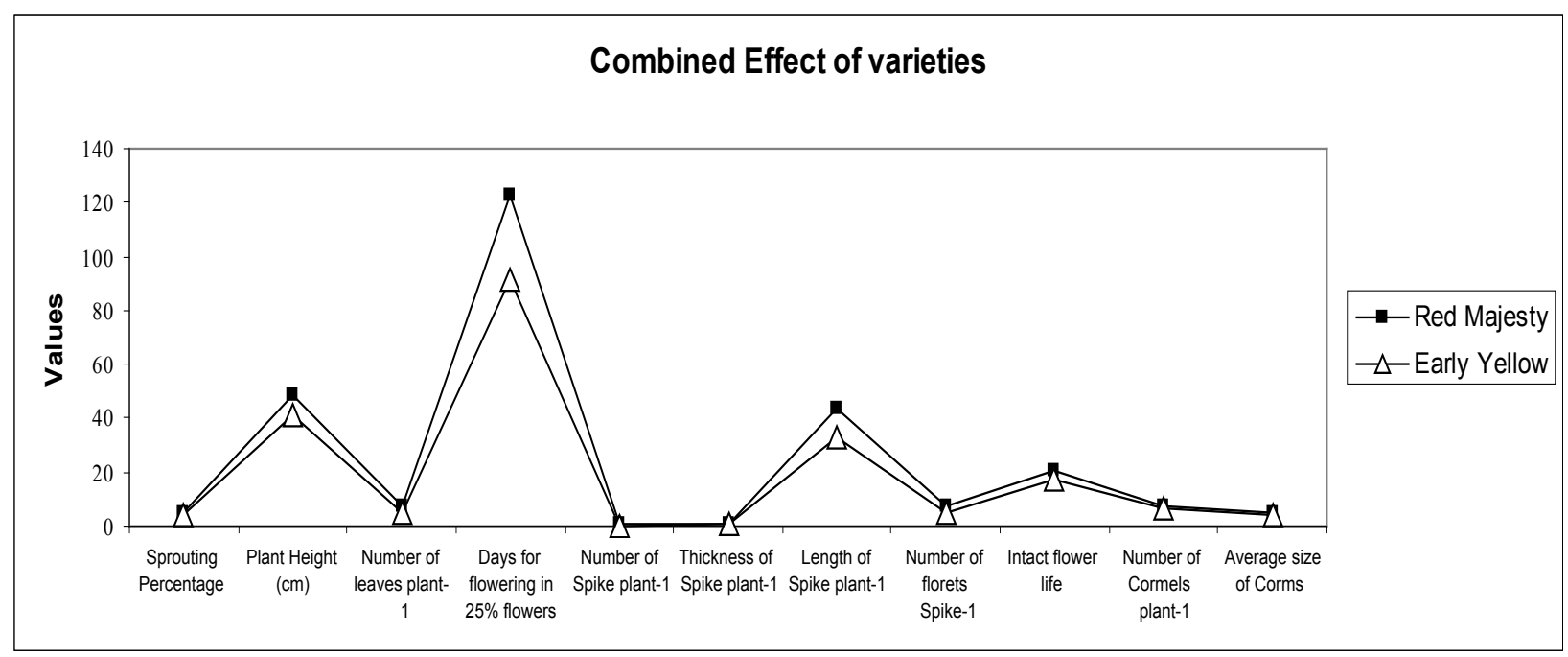

Figure 4. Combined effect of varieties

\section{Length of spike plant ${ }^{-1}$}

Plants raised by medium and large sized corms produced spikes of maximum length in both cultivars being $47.55 \mathrm{~cm}$ and $47.50 \mathrm{~cm}$ in cv. Red Majesty and 45.56 and $43.11 \mathrm{~cm}$ in cvs. Early Yellow respectively. Spike length was too much reduced in cvs. Early Yellow i.e. $10.89 \mathrm{~cm}$ when small sized corms were used as planting materials. Results depict that for commercial purpose only medium or large sized corms should be used which has high market value.

Number of florets spike ${ }^{-1}$

Corm size significantly affected number of floret spike ${ }^{-1}$. Number of floret spike ${ }^{-1}$ was statistically more when medium and large sized corms were planted. Corms of medium and large sized produced 7.82 and 8.31 floret spike ${ }^{-1}$ in cv. Red Majesty. While 7.30 and 6.77 floret spike in cv. Early Yellow. Small corms in both cv. produced small sized spike, bearing less number of florets $5.85 \mathrm{in} \mathrm{cv}$. Red Majesty and 3.62 in cv (Figure 3, 4). Early Yellow. Number of florets spike-1 in case of small sized corm was statistically at par with these from medium and large sized corms depicting the superiority of $\mathrm{cv}$. Red Majesty over Early Yellow for commercial point of view.

\section{Intact Flower Life}

Corm size significantly affected the intact flower life of both cultivars. The life of flower was maximum (22.12 days) when planted through large sized corms while 21.78 days when raised through medium sized corms in cv. Red Majesty. In case of Early Yellow, intact flower life was maximum (21.35 days) and 21.69 days when planted through large sized corms and medium sized corms respectively. Small sized corms had least flower life; 16.64 days and 8.56 days in cvs. Red Majesty and Early Yellow respectively. Number of cormels plant ${ }^{-1}$ :

More number of cormels plant ${ }^{-1}$ was produced by plants raised by corms of large sized. Number of cormels was at par for both medium and large sized being 8.50 and $8.67 \mathrm{in} \mathrm{cv}$. Red Majesty respectively. While 8.33 for both corms sizes in cv. Early Yellow. Number of cormels plant ${ }^{-1}$ from small sized plants was almost half i.e. 4.48 and 4.43 cormels plant $^{-1}$ in cv. Red Majesty respectively. Results signify the importance of medium or large sized corms for propagation material to produce more number of cormels which will increase the net profit for a unit area.

\section{Average Number of Corms}

Corms size was increased with increase corm size. Maximum corm size was observed on corm size $(3-3.5 \mathrm{~cm})$ in Red Majesty $(5.90 \mathrm{~cm})$ and minimum corm size was observed in corm size $(1-1.5 \mathrm{~cm})$ in Early Yellow $(1.83 \mathrm{~cm})$. The combined effect indicate there is increases in corm size with treatment $(3-3.5 \mathrm{~cm}), \quad(2-2.5 \mathrm{~cm})$ and $(1-1.5 \mathrm{~cm})$ respectively as shown in Figure 4. The corms of variety Red Majesty attain more corm sizes as compared to Early Yellow (Figure 4).

\section{Conclusion}

Positive relationship occurs between the large sized corms (3 to $3.5 \mathrm{~cm}$ ), vegetative and reproductive growth of Gladiolus grandiflorus cvs. Red Majesty and Early Yellow i.e. large sized corms produced maximum sprouting percentage $(96.67 \%)$, maximum plant height $(56.02 \mathrm{~cm})$, maximum number of leaves plant ${ }^{-1}(7.720)$, minimum days required for $25 \%$ flowers (149.4 and 150.0 days in cvs. Red Majesty and Early Yellow respectively), maximum spike thickness $(1.023 \mathrm{~cm})$, maximum length of spike plant ${ }^{-1}$ $(47.55 \mathrm{~cm}$ and $47.50 \mathrm{~cm}$ in cvs. Red Majesty and 45.56 and $43.11 \mathrm{~cm}$ in cvs. Early Yellow respectively), maximum number of florets spike-1(8.31 floret spike $\left.{ }^{-1}\right)$, maximum number of cormels plant ${ }^{-1}(8.67)$, maximum average number of corms $(5.90 \mathrm{~cm})$ and maximum intact flower life $(22.12$ days). Different corm size had no effect on number of spikes plant $^{-1}$. Therefore, large sized corms ( 3 to $3.5 \mathrm{~cm}$ ) should be used for best quality of Gladiolus grandiflorus cvs. Red Majesty and Early Yellow under agro-ecological conditions 
of Faisalabad.

\section{REFERENCES}

[1] Ahmad, T., I. Ahmad and M. Qasim. Present status and future prospects of gladiolus cultivation in Punjab, Pakistan. J. Tekirdag Agric. Faculty. (In Press).

[2] Arora, J.S. and K. Khanna. 1990. Studies on corm production in gladiolus as affected by different corm sizes. Indian J. Hort. 47: 442-446.

[3] Farid Uddin M. R., Md. Moshiur and Md.G. Rabbani. 2002. Effect of different corm size and depth of planting on growth and flowering of gladiolus. Pak. J. Bio. Sci. 5(5): 535-555.

[4] Hudson, T.H., J.F. William and M.K. Anton. 1981. Plant Sciences. Engle Wood Clifts. New Jersey, 07632, USA. Pp. 676.

[5] Kalasareddi, P.T., B.S. Reddy, S.R.Patil, Y.H. Ryagi and
P.M. Gangadharappa. 1997. Effect of corm size on flowering and flower yield of gladiolus cv. Snow White. Karnataka J. Agric. Sci. 10(4): 1228-1230.

[6] Korkut, A.B., S.J. Butt and E. Dozalan. 1997. Effect of different harvesting times on the corm yield and quality of gladiolus. Pak. J. Sci. Hort. 41(4): 199-202.

[7] Mahanta, P., L. Paswan and A.B. Siddique. 1998. Effect of bulb size on growth and flowering of tuberose (Polianthus tuberose L.) cv. Single. Annals. Agri. Bio. Res. 3(1): 35-38.

[8] Mitra, R. 1992. Gladiolus. In: Fuler Bagan (In Bangla) 3rd ed. Indian Book Academy, Calcutta, India.Pp. 158-168.

[9] Mukhopadhay, T.K. and L.P. Yadav. 1995. Effects of corm size and spacing on growth, flowering and production of gladiolus. Haryana J. Hort. Sci. 13: 95-99.

[10] Ogale, V.K. and V.A. Rode and S.D. Mishra. 1995. Role of corm size in gladiolus flowering and final (corm) yield. Ind. J. Pl. Phy. 38(3): 241-24.

[11] Sharga, A.N. 1982. Effect of bulb size on vegetative growth and flower characters of tuberose (Polianthus tuberose L.). Progressive Hort. 14(4): 258-260. 